(C) 2013

\author{
Вдовенко С. А., кандидат сільськогосподарських наук
}

Вінницький національний аграрний університет

\title{
ФОРМУВАННЯ ВРОЖАЮ ГЛИВИ ЗВИЧАЙНОЇ ЗА ІНТЕНСИВНОГО ВИРОЩУВАННЯ
}

\section{Рецензент - доктор сільськогосподарських наук, професор І. Ф. Підпалий}

Розглядаються особливості виробництва двох итамів гливи звичайної на субстраті з соломи пшениці, ячменю, гороху. Встановлено особливості плодоношення гриба й отримання товарної продукиії в умовах захищеного трунту. Визначено, шяо солому горохову слід використовувати для приготування субстрату у разі вирощування гливи звичайної; вказаний субстрат характеризується швидким настанням фаз росту й розвитку гриба, збільшується загальна врожайність і покращується товарність продукиії.

Ключові слова: субстрат, тіла плодові, урожайність, ефективність використання субстрату, коефіцієнт, товарність.

Постановка проблеми. Виробництво їстівних грибів за інтенсивним способом є безвідходною технологією, поскільки вирішується питання забезпечення населення свіжою продукцією, а субстрат використовують як органічне добриво для рослин відкритого грунту [5]. Окрім шампіньйона двоспорового з'явились інші види грибів, які успішно вирощують у зимово-весняний період, а саме: глива звичайна, шиї-таке, кільцевик, вольваріела вольвова, зимовий гриб, опеньок літній. Деякі види їстівних грибів вирощують на присадибних ділянках у простих і дешевих приміщеннях, а інші в спеціалізованих виробничих комплексах $[6,7,9]$.

Найбільше їстівних грибів вирощують у Китаї, а серед країн Свропи - у Нідерландах, Польщі, Франції, Італії, Німеччині, Угорщині. В Європі та США перевагу віддають шампіньйону двоспоровому, проте останнім часом простежується тенденція до збільшення виробництва гливи звичайної та шиї-таке. Ї̈ виробництво за останні роки збільшується, що пов'язано $з$ поживністю та простою технологією. Крім того вони мають цінні лікувальні властивості. Завдяки досягненням технічного прогресу, технологіям виробництва та інтенсивній селекційній роботі середня урожайність шампіньйона двоспорового в окремих країнах збільшилася з 4-6 до 30-40 кг $/ \mathrm{m}^{2}$ за один цикл вирощування, а гливи звичайної - до 1,0-1,2 кг/кг субстрату $[1,11,12]$.

Аналіз останніх досліджень i публікацій, у яких започатковано розв'язання проблеми. Для успішного вирощування гриба велику увагу приділяють складовим компонентам субстрату.
Для цього використовують такі матеріали як: солому злакових рослин (пшениці, жита), рідше рештки кукурудзи та ячменю чи квасолі або їх суміш, тирсу і кору листяних порід дерев, соняшникове лушпиння. Згідно $з$ даними D. J. Rouse, S. A. Zaki [13] та S.C. Dubey [10], найбільш оптимальним субстратом у вирощуванні гливи звичайної $є$ пшенична солома, яка досить добре реагує на додатки до субстрату, які в послідуючому сприяють збільшенню загальної врожайності тіл плодових. Однак отримати повноцінний субстрат, що забезпечує високу врожайність їстівних грибів, не завжди вдається, поскільки від складу субстрату, його структури, кислотності середовища, вологості, вмісту елементів живлення залежить подальше створення умов для розвитку гриба.

У процесі своєї життєдіяльності міцелій гливи звичайної з субстрату отримує воду, поживні речовини, а в субстрат виділяє метаболіти $[4$, 14]. Середовище повинно містити в достатній кількості азот, вуглець, різні мінеральні домішки, вітаміни і забезпечувати нормальні умови для життєдіяльності гриба. Розгалужена структура гіф у субстраті сприяє просторовому переміщенню поживних речовин, у тому числі важких сполук [3]. На думку О. В. Федотова [8], кращими вуглецевмісними компонентами живильного середовища для отримання біомаси і підвищення каталазної активності міцелію $є$ глюкоза, сахароза.

На основі досліджень М. Ziombry [15] встановлено вплив субстрату на величину врожаю та морфологічні показники тіл плодових гливи звичайної. Використання 24 кг субстрату дозволяє отримати урожайність на рівні 928 г з 1 кг сухої маси субстрату, а найменшу врожайність - при використанні 8 кг субстрату в контейнері. Така кількість субстрату сприяє одночасно отриманню високого вмісту стандартної продукції, однак спостерігаються зміни у морфологічних особливостях тіл. Вміст товарної продукції в загальній врожайності $€$ досить вирівняним і становить $77 \%$.

Аналіз літературних джерел показав, що недостатньо є даних про використання компонентів субстрату, як соломи інших сільськогосподарських рослин, а саме ячменю та гороху, для вирощування гливи зви- 


\section{СІЛЬСЬКЕ ГОСПОДАРСТВО. РОСЛИННИЦТВО}

чайної в умовах захищеного грунту. Виробництво зазначених рослин в Україні у відкритому грунті знаходиться на досить високому рівні, однак їх вплив на отримання свіжої продукції вивчено не повністю.

Метою досліджень було визначення врожайності гливи звичайної залежно від використання соломи пшениці, ячменю та гороху для отримання продукції гливи звичайної в зимово-весняний період.

Для досягнення мети вирішувались такі завдання: оцінити солом'яні субстрати та дослідити найефективніший 3 них для подальшого вирощування гливи звичайної за інтенсивного вирощування; провести товарну оцінку штамів гриба на солом'яних субстратах і підібрати найбільш високоврожайний.

Методика досліджень. Досліди над вивченням впливу субстрату на врожайність гливи звичайної закладені в лабораторії кафедри плодівництва, овочівництва та технології зберігання і переробки сільськогосподарської продукції Вінницького національного аграрного університету в 2006-2007 роках згідно 3 рекомендаціями І. А. Дудки [2]. Досліджувалися два штами гливи звичайної: НК-35 та Р-24 на субстраті, основу якого складала солома пшенична, ячмінна чи горохова. Контролем слугував субстрат iз соломи пшеничної. Солома заготовлялася 3 останніх жнив i оброблялась ксеротермічним способом. Після обробітку субстрат наповнювався в поліетиленові мішки, які встановлювалися рядковим способом. Досліди проводились у трьохкратній повторності методом рендомізованих блоків.
Під час досліджень використовували загальноприйняті в агрономії методи досліджень 3 проведенням обліку врожаю гливи звичайної. Одержані дані оброблялися статистичним методом дисперсійного аналізу на ПК із використанням прикладних програм Microsoft Excel.

Результати досліджень. Настання основних фаз росту й розвитку гливи звичайної є показником, який характеризує відповідність умов вирощування до морфо-біологічних особливостей гриба: чим оптимальніші умови вирощування, тим інтенсивніше протікають процеси росту i розвитку. В дослідженнях настання фаз залежало як від штаму, так і від виду субстрату, що в результаті вплинуло на загальну врожайність i товарність гливи звичайної.

Урожайність гриба складалася 3 двох хвиль плодоношення, що становили загальну врожайність. Тіла плодові характеризувалися типовою формою, мали властиве забарвлення і за біометричними показниками відповідали встановленим вимогам. Оцінюючи ефективність впливу субстратів на врожайність гливи звичайної, стверджено перевагу субстрату, основу якого складала солома горохова. Перевага врожайності обумовлена передусім підвищеним вмістом білків та вуглеводів у субстраті, що сприяло інтенсивному росту міцелію та утворенню значної кількості примордіїв гриба. Величина тіл плодових штамів НК-35 та Р-24 на соломі гороховій становила 18,5 і 19,7 кг/м², що перевищувало врожайність контрольного варіанту у 1,1 разу.

1. Урожайність гливи звичайної залежнно від виду субстрату, кz/м²

\begin{tabular}{|c|c|c|c|c|c|c|c|c|}
\hline \multirow[b]{2}{*}{ 嶌 } & \multirow[b]{2}{*}{ Субстрат } & \multicolumn{3}{|c|}{ Урожайність, кг $/ \mathrm{M}^{2}$} & \multirow{2}{*}{$\begin{array}{l} \pm \text { до } \\
\text { конт- } \\
\text { ролю }\end{array}$} & \multirow{2}{*}{$\begin{array}{c}\text { Ефек- } \\
\text { тивність } \\
\text { викорис- } \\
\text { тання суб- } \\
\text { страту, \% }\end{array}$} & \multirow{2}{*}{$\begin{array}{c}\text { Коефі- } \\
\text { цієнт вико- } \\
\text { ристання } \\
\text { субстрату }\end{array}$} & \multirow{2}{*}{$\begin{array}{c}\text { Біоло- } \\
\text { гічна } \\
\text { ефек- } \\
\text { тив- } \\
\text { ність, \% } \\
\end{array}$} \\
\hline & & $2006 \mathrm{p}$. & 2007 p. & $\begin{array}{c}\text { середне } \\
\text { зароки }\end{array}$ & & & & \\
\hline \multirow{3}{*}{ 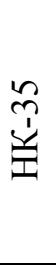 } & $\begin{array}{l}\text { солома } \\
\text { пшенична * }\end{array}$ & 14,9 & 17,4 & 16,1 & - & 54,1 & 0,13 & 46,3 \\
\hline & $\begin{array}{l}\text { солома } \\
\text { ячмінна }\end{array}$ & 15,4 & 16,2 & 15,8 & $-0,3$ & 50,4 & 0,10 & 45,4 \\
\hline & $\begin{array}{l}\text { солома } \\
\text { гороху }\end{array}$ & 17,6 & 19,9 & 18,5 & $+2,4$ & 64,6 & 0,17 & 48,6 \\
\hline \multirow{3}{*}{$\underset{\sim}{\stackrel{T}{\Lambda}}$} & $\begin{array}{l}\text { солома } \\
\text { пшенична * }\end{array}$ & 15,9 & 18,9 & 17,4 & - & 50,4 & 0,14 & 34,8 \\
\hline & $\begin{array}{l}\text { солома } \\
\text { ячмінна }\end{array}$ & 13,9 & 19,1 & 16,5 & $-0,9$ & 49,6 & 0,12 & 34,4 \\
\hline & $\begin{array}{l}\text { солома } \\
\text { гороху }\end{array}$ & 18,9 & 20,6 & 19,7 & $+2,3$ & 54,7 & 0,17 & 35,4 \\
\hline & $\mathrm{HIP}_{05}$ & 0,73 & 1,42 & & & & & \\
\hline
\end{tabular}

Примітка: *-контроль 


\section{СІЛЬСЬКЕ ГОСПОДАРСТВО. РОСЛИННИЦТВО}

Крім позитивного впливу субстрату дослідами визначено тенденцію щодо зменшення врожайності тіл плодових у варіанті, в якому до складу субстрату входила солома ячмінна. Так, величина врожайності штаму Р-24 зменшувалася на субстраті з соломи ячмінної майже на 1 кг/ $\mathrm{M}^{2}$, а по штаму НК-35 - на 0,3 кг $/ \mathrm{M}^{2}$ (табл. 1).

Водночас дослідами встановлена різна ефективність використання міцелієм поживних елементів із субстрату та коефіцієнт використання поживних елементів із субстрату. За період проведення досліду вказані показники були змінними величинами. Найбільшим значенням цих показників (по відношенню до контролю) характеризувався штам гливи звичайної НК-35, який вирощувався на соломі гороховій. Величина ефективності використання горохового субстрату становила 64,6\%, а коефіцієнт використання поживних елементів із субстрату знаходився на рівні 0,17. Меншим значенням ефективності використання поживних елементів із субстрату горохового встановлено по штаму Р-24.

У процесі вирощування гливи звичайної на субстраті з соломи ячмінної процеси росту й розвитку гриба проходили 3 незначною затримкою, волога використовувалася міцелієм не належним чином, що вплинуло на плодоношення та використання елементів живлення з соломи, а тому показник ефективності використання субстрату незалежно від штаму гриба був найнижчим.

Інтенсивність використання поживних речовин суттєво вплинуло й на біологічну ефективність субстрату. В дослідах вказаний показник був невисоким. Найбільше значення його спостерігалось у варіанті з використанням соломи горохової по штаму НК-35, а саме 48,6\%, а найменшим - на субстраті з соломи ячмінної по штаму Р-24.

Урожайність гливи звичайної на субстратах визначила неоднакове плодоношення. Серед досліджуваних штамів найвищою загальною врожайністю тіл плодових характеризувався штам НК-35, у якого величина врожаю становила 767,9 г/кг субстрату, а нижчим урожаєм штам P-24 3 урожайністю в 735 г/кг субстрату. Різниця в урожайності штамів становила аж 32,9 грамів. Математичний обробіток підтвердив достовірність отриманих даних (див. рис.).

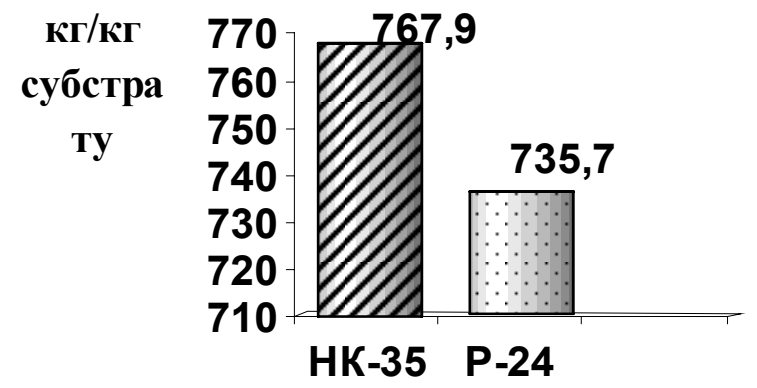

\section{Рис. Величина врожаю гливи звичайної залежно від итаму, кг/кг субстрату}

Товарність врожаю оцінювалася по двох товарних групах тіл плодових гриба та групи нестандарту. Під час проведення аналізу тіла плодові були типовими для кожного штаму 3 відповідним забарвленням шапинки, формою, - вони знаходились у технічній стиглості й не були пошкоджені шкідниками та хворобами (табл. 2).

На основі отриманих даних відмічено високу товарність штамів, вирощених на соломі гороховій. Так, загальна кількість плодових тіл, із діаметром шапинки 40-60 мм, у даному варіанті становила близько 90,3-91,6 \% по досліджуваних штамах.

У інших варіантах загальна кількість тіл плодових вказаної групи була меншою, проте вони відповідали вимогам стандарту.

\section{2. Товарна оцінка тіл плодових гливи звичайної в досліді (середнє за 2006-2007 рр.)}

\begin{tabular}{|c|c|c|c|c|c|c|c|}
\hline \multirow{3}{*}{ Штами } & \multirow{3}{*}{ Субстрат } & \multicolumn{4}{|c|}{$\begin{array}{l}\text { Вміст товарних тіл плодових у загально- } \\
\text { му врожаї залежно від діаметра шапинки }\end{array}$} & \multicolumn{2}{|c|}{$\begin{array}{l}\text { Нестандартні } \\
\text { тіла плодові }\end{array}$} \\
\hline & & \multicolumn{2}{|c|}{ I група } & \multicolumn{2}{|c|}{ II група } & КГ & $\%$ \\
\hline & & КГ & $\%$ & кГ & $\%$ & КГ & $\%$ \\
\hline \multirow{3}{*}{ HК-35 } & солома пшенична* & 13,8 & 86,8 & 1,94 & 12,1 & 0,36 & 1,1 \\
\hline & солома ячмінна & 13,4 & 85,1 & 2,15 & 13,6 & 0,25 & 1,3 \\
\hline & солома горохова & 16,9 & 90,3 & 1,7 & 9,0 & 0,1 & 0,7 \\
\hline \multirow{3}{*}{ P-24 } & солома пшенична* & 15,5 & 89,5 & 1,6 & 9,6 & 0,3 & 0,9 \\
\hline & солома ячмінна & 14,5 & 87,9 & 1,8 & 10,9 & 0,2 & 1,2 \\
\hline & солома горохова & 18,0 & 91,6 & 1,5 & 7,8 & 0,2 & 0,6 \\
\hline
\end{tabular}

Примітка: * - контроль 


\section{СІЛЬСЬКЕ ГОСПОДАРСТВО. РОСЛИННИЦТВО}

Найбільшою кількістю тіл плодових II групи 3 діаметром шапинки 60-100 мм характеризувався субстрат, приготовлений на основі ячмінної соломи: по штаму НК-35 кількість тіл плодових становила 13,6 \%, а по штаму Р-24 - 10,9\% відповідно. Тіла, що не відповідали вимогам стандарту, характеризувалися незначним вмістом. У загальному врожаї кількість нестандартних тіл плодових не перевищувала $1,2 \%$.

У проведених дослідженнях існує вплив субстрату на врожайність гливи звичайної. Дослідженнями визначено, що солому горохову можна використовувати для приготування субстрату до виробництва гриба, де одержано найвищу врожайність по відношенню до соломи ячмінної та пшеничної.

\section{БІБЛІОГРАФІЯ}

1. Абросимова Г.Л. Інтенсивна технологія вирощування плеврота звичайного / Г. Л. Абросимова, А. Н. Лисенко //Вісник аграрної науки. - 1996. - № 3. - C. 18-21.

2. Дудка И. А., Вассер С. П., Бисько Н. А. [и др.]. Методические рекомендации по промышленному культивированию съедобных грибов. - К. : Наукова думка, 1987. - 69 с.

3. Захаренко О. А. Правильный субстрат для вешенки / О. А. Захаренко // Настоящий хозяин. - 2007. - №7/8. - C. 58-61.

4. Круподьорова Т. А. Альтернативні субстрати для культивування лікарських та їстівних грибів / Т. А. Круподьорова, В. Ю. Барштейн // Мікробіологія і біотехнологія. - 2012. - №5. - С. 47-55.

5. Ліпник $М$. Штучне культивування їстівних грибів / М. Ліпник, А. Бісько, В. Білай // Техніка АПК. - 1997. - № 1. - С. 24-26.

6. Мануковский Н. С. Использование остаточного субстрата при выращивании вешенки Pleurotus Florida Fovose / Н. С. Мануковский // Микология и фитопатология. - 1998. - Т. 32. - Вып. 6. - С. 43-46.

7. Пивень И. О. Методические указания по выращиванию грибов вешенки и шампиньона. Мерефа, 1994. - 24 c.

8. Вплив джерел вуглецевого живлення на ріст i каталазну активність P-6v Pleurotus ostreatus (Jacq. Ex Fr) Kumm. [Електронний ресурс] / О. В. Федотов, О. М. Брусніцина // Хімія і Біологія. 2008. - С.248-251. - Режим доступу:
Висновки:

1. Солому горохову слід використовувати для приготування субстрату в процесі вирощування гливи звичайної. Вказаний субстрат характеризується швидким проходженням основних фаз росту й розвитку гриба, збілышується загальна врожайність

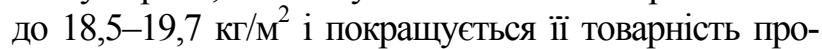
дукщіі.

2. Субстрат із соломи ячмінної також можна використовувати для виробництва гливи звичайної, однак він характеризується нижчими показниками врожайності.

3. Найвищою урожайністю грибів $(767,9$ г/кг субстрату) характеризувався штам НК-35, а нижчим урожаєм - штам P-24.

http://www.nbuv.gov.ua/portal/Chem_Biol/peop/2008/2 48-251/pdf.

9. Шаталова А. Б. Вешенка - перспективная культура / А. Б. Шаталова, К. П. Наханова // Картофель и овощи. - 1997. - № 5. - С. 30-33.

10. Dubey S.C. Effect of different substrates and amendments on yield of Pleurotus sp. / S. C. Dubey // Mycol. Plant Pathol. - 1999. - № 29. - P. 209216.

11. Gapiński M. Boczniak / M. Gapiński, W. Wozniak, M. Ziombra. - Poznan: PWRiL, 1992. - $148 \mathrm{~s}$.

12. Gapiński M. Boczniak - technologia uprawy i przetwarzania / M. Gapiński, W. Wożniak, M. Ziombra. - Poznań: PWRiL, 2001. - 264 s.

13. Royse D. J. Yield stimulation of Pleurotus flabellatus by dual nutrient supplementation of pasteurized wheat straw / D. J. Royse, S. A. Zaki Science and cultivation of edible fungi. Red. M. J. Maher. - Rotterdam: Balkema, 1991. - P. 545-547.

14. Wożniak $W$. Wpływ podłoża uprawowego na skład boczniaka ostrygowatego (Pleurotus ostreatus (Fr.) Kumm) / W. Wożniak, E. Sobkowska, M. Gapiński, M. Ziombra / Priblemy Higieny. - 1987. - №32. S. 86-98.

15. Ziombra M. Plonowanie boczniaka Pleurotus Precoce (Fr.) Quel w zależności od masy podłoża / M. Ziombra, A. Czerwińska, K. Lawicka // Roczniki akademii rolniczej w Poznaniu. - 2007. CCCLXXXIII, Ogrodnictwo 41. - S. 673-677. 